\title{
Corynebacterium doosanense sp. nov., isolated from activated sludge
}

Correspondence
Wonyong Kim
kimwy@cau.ac.kr

\author{
Hee Joong Lee, Sung-Lim Cho, Min Young Jung, Thi Hai Van Nguyen, \\ Yeon-Chang Jung, Hee Kuk Park, Van Phan Le and Wonyong Kim
}

\begin{abstract}
Department of Microbiology and Research Institute for Translational System Biomics, Chung-Ang University College of Medicine, 221 Heukseok-dong, Dongjak-gu, Seoul 156-756, Republic of Korea
\end{abstract}

The genus Corynebacterium was established by Lehmann \& Neumann (1896) and represents one of the largest groups within the Actinobacteria. At the time of writing, Corynebacterium comprised 95 recognized taxa. In recent years, many of the recognized species within this genus originated from clinical specimens of humans (Hall et al., 2003; Renaud et al., 2007; Yassin, 2007; Yassin \& Siering, 2008), animals (Goyache et al., 2003a, b; FernándezGarayzábal et al., 2003, 2004; Collins et al., 2004; Vela et al., 2006) and environments (Yassin et al., 2003; Chen et al., 2004; Feurer et al., 2004). Until now, however, there have been relatively few reports of corynebacteria from activated sludge. During the course of routine screening of bacteria for industrial purposes, a Corynebacterium-like strain, designated CAU $212^{\mathrm{T}}$, was isolated from activated sludge from the wastewater treatment plant in Yeongdeuk-gun, Republic of Korea.

The isolation procedure for strain CAU $212^{\mathrm{T}}$ followed that of Gordon \& Mihm (1962) by using glucose-yeast extract agar (GYEA; comprising per litre: $10 \mathrm{~g}$ yeast extract, $10 \mathrm{~g}$ glucose and $15 \mathrm{~g}$ agar) supplemented with $50 \mathrm{mg}$ cycloheximide $1^{-1}$ and $20 \mathrm{mg}$ nalidixic acid $\mathrm{l}^{-1}$. An activated sludge sample was diluted with sterilized distilled water and appropriate dilutions were spread onto the GYEA medium and incubated aerobically for 3 days at $30{ }^{\circ} \mathrm{C}$. An opaque, yellow, low-convex bacterial colony with a diameter of 1-2 mm was subcultured on sheep blood agar plates (Asan

Abbreviation: CAMP, Christie-Atkins-Munch-Petersen.

The GenBank/EMBL/DDBJ accession number for the 16S rRNA gene sequence of strain CAU $212^{\top}$ is EU998655.
Pharm Co.). The pure culture of CAU $212^{\mathrm{T}}$ was preserved in $25 \%(\mathrm{v} / \mathrm{v})$ glycerol at $-70{ }^{\circ} \mathrm{C}$. The cell morphology of colonies was observed at different incubation times, every $24 \mathrm{~h}$ for 3 days, with a microscope following Gram staining.

Strain CAU $212^{\mathrm{T}}$ was characterized biochemically using the API Coryne, API 20 Strep and API ZYM kits (bioMérieux) according to the manufacturer's instructions. The ChristieAtkins-Munch-Petersen (CAMP) test with Staphylococcus aureus was performed as described by von Graevenitz \& Funke (1996). Cell-wall murein was prepared by mechanical disruption of cells and complete acid hydrolysates were analysed as described by Schleifer \& Kandler (1972). Cellular fatty acid methyl esters were extracted by acid methanolysis (Minnikin et al., 1980) and analysed by using a Hewlett Packard series II gas chromatograph model $5890 \mathrm{~A}$ equipped with a $5 \%$ phenyl methyl silicon-fused silica capillary column (HP 19091B-102). The presence of mycolic acid was investigated by GLC analysis of trimethylsilylated derivatives (Klatte et al., 1994).

Genomic DNA of strain CAU $212^{\mathrm{T}}$ was isolated and purified by using the method of Marmur (1961). The DNA $\mathrm{G}+\mathrm{C}$ content was measured by using the thermal denaturation method (Marmur \& Doty, 1962). PCR amplification and sequencing of the 16S rRNA gene were carried out following established procedures (Nam et al., 2004). The amplified 16S rRNA gene was sequenced directly using a BigDye Terminator Cycle Sequencing kit (Applied Biosystems) and an automatic DNA sequencer (model 3730; Applied Biosystems). Multiple alignments 
with sequences of a broad selection of corynebacteria and calculations of sequence similarity levels were carried out by using CLUSTAL X (Thompson et al., 1997) and the EzTaxon server (Chun et al., 2007). A phylogenetic tree was constructed using the neighbour-joining algorithm (Saitou \& Nei, 1987) from the PHYLIP suite of programs (Felsenstein, 1989). Evolutionary distances for the neighbour-joining analysis were based on the correction of Jukes \& Cantor (1969). Tree topology was evaluated by using the bootstrap resampling method with 1000 replicates (Felsenstein, 1985) of the neighbour-joining dataset with the SEQBOOT and CONSENSE programs from the PHYLIP package.

Colonies of strain CAU $212^{\mathrm{T}}$ on GYEA plates growing under aerobic conditions at $30{ }^{\circ} \mathrm{C}$ for 3 days were yellow, opaque, low-convex and approximately $1-2 \mathrm{~mm}$ in diameter. On sheep blood agar after $48 \mathrm{~h}$ of incubation, colonies were small (about $1 \mathrm{~mm}$ in diameter), yellow, opaque and non-haemolytic. Microscopic examination of the cells showed Gram-positive, non-motile, irregular and club-shaped rods, a typical coryneform morphology. Mycelia and spores were not observed. Cells were catalaseand oxidase-positive. API Coryne, API 20 Strep and API ZYM test strips provided adequate phenotypic data to describe the novel isolate and a detailed description of the key phenotypic characteristics of the isolate is given in Table 1 and in the species description.

Using the API Coryne system, positive results were obtained for the production of pyrazinamidase, production of acid from glucose and reduction of nitrate. The API Coryne code for strain CAU $212^{\mathrm{T}}$ was 3000104 and generated poor confidence levels towards Corynebacterium accolens, C. striatum/amycolatum and C. argentoratense when compared with API Coryne database version 3. Results from the API 20 Strep system were positive for sodium pyruvate and hippuric acid hydrolysis. The API
ZYM test detected esterase lipase (C8), leucine arylamidase and naphthol-AS-BI-phosphohydrolase. The CAMP test was negative. An examination of acid hydrolysate of cellwall murein revealed the presence of meso-diaminopimelic acid as the dibasic amino acid. TLC analysis of whole-cell hydrolysates detected mainly galactose and arabinose. Short-chain mycolic acids were also detected. Predominant fatty acids corresponded to $\mathrm{C}_{14: 0}(0.3 \%)$, $\mathrm{C}_{16: 1} \omega 9 c(1.1 \%), \mathrm{C}_{16: 0}(18.8 \%), \mathrm{C}_{18: 1} \omega 9 c(67.0 \%)$ and $\mathrm{C}_{18: 0}(9.9 \%)$. The major long-chain cellular fatty acids of the organism were $\mathrm{C}_{12: 0}(3 \%), \mathrm{C}_{14: 0}(4 \%), \mathrm{C}_{16: 0}(28 \%)$, $\mathrm{C}_{18: 0}(25 \%), \mathrm{C}_{18: 1} \omega 9 c(28 \%), \mathrm{C}_{18: 1} \omega 7 c(1 \%)$ and $\mathrm{C}_{20: 0}$ (2\%). Small amounts of short-chain mycolic acids (C2232) were also detected. The DNA G $+\mathrm{C}$ content of strain CAU $212^{\mathrm{T}}$ was $53.5 \mathrm{~mol} \%$.

The nearly complete $16 \mathrm{~S}$ rRNA gene sequence of strain CAU $212^{\mathrm{T}}$ (1494 bp) was determined and compared with the corresponding sequences of other bacterial strains in the GenBank database. A phylogenetic tree, based on $16 \mathrm{~S}$ rRNA gene sequence data from strain CAU $212^{\mathrm{T}}$ and corresponding sequences from the type strains of recognized corynebacteria as well as Tsukamurella paurometabola DSM 20162 ${ }^{\mathrm{T}}$, was constructed according to the neighbour-joining algorithm (Fig. 1). The genus Corynebacterium embraces a very diverse range of organisms and it is recognized that the genus is not monophyletic and comprises several distinct 16S rRNA gene lineages. The tree topology, supported by high bootstrap values, clearly separated strain CAU $212^{\mathrm{T}}$ within the genus Corynebacterium. It is evident from our 16S rRNA gene sequence study that strain CAU $212^{\mathrm{T}}$ is a distinct member of the subclade containing Corynebacterium hansenii C$138^{\mathrm{T}}$, C. xerosis ATCC $373^{\mathrm{T}}$, C. freneyi ISPB $6695110^{\mathrm{T}}$ and C. halotolerans YIM $70093^{\mathrm{T}}$ within the phylogenetic tree. Pairwise similarity values ranged between $95.7 \%$ ( $C$. hansenii CIP $108444^{\mathrm{T}}$ ) and $90.3 \%$ (C. hoagii ATCC $\left.7005^{\mathrm{T}}\right)$. High sequence divergence values $(>4.3 \%)$ with

Table 1. Differential phenotypic properties of strain CAU $212^{\top}$ and its closest phylogenetically related species

Strains: 1, CAU $212^{\mathrm{T}}$ (C. doosanense sp. nov.); 2, C. hansenii CIP $108444^{\mathrm{T}} ; 3$, C. singulare CCUG $37330^{\mathrm{T}} ; 4$, C. minutissimum $\mathrm{NCTC}^{10288^{\mathrm{T}}}$; 5 , C. xerosis ATCC $373^{\mathrm{T}} ; 6$, C. freneyi ISPB $6695110^{\mathrm{T}} ; 7$, C. halotolerans YIM $70093^{\mathrm{T}}$. All strains produce acid from glucose. All data are from this study. + , Positive; -, negative; $v$, variable.

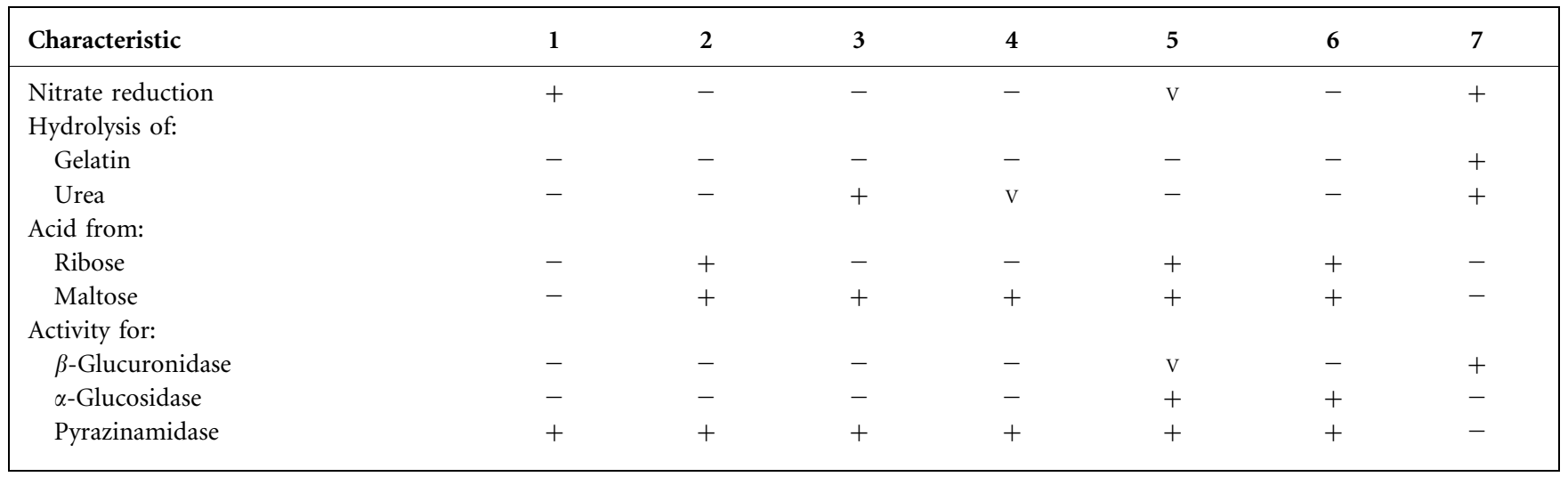




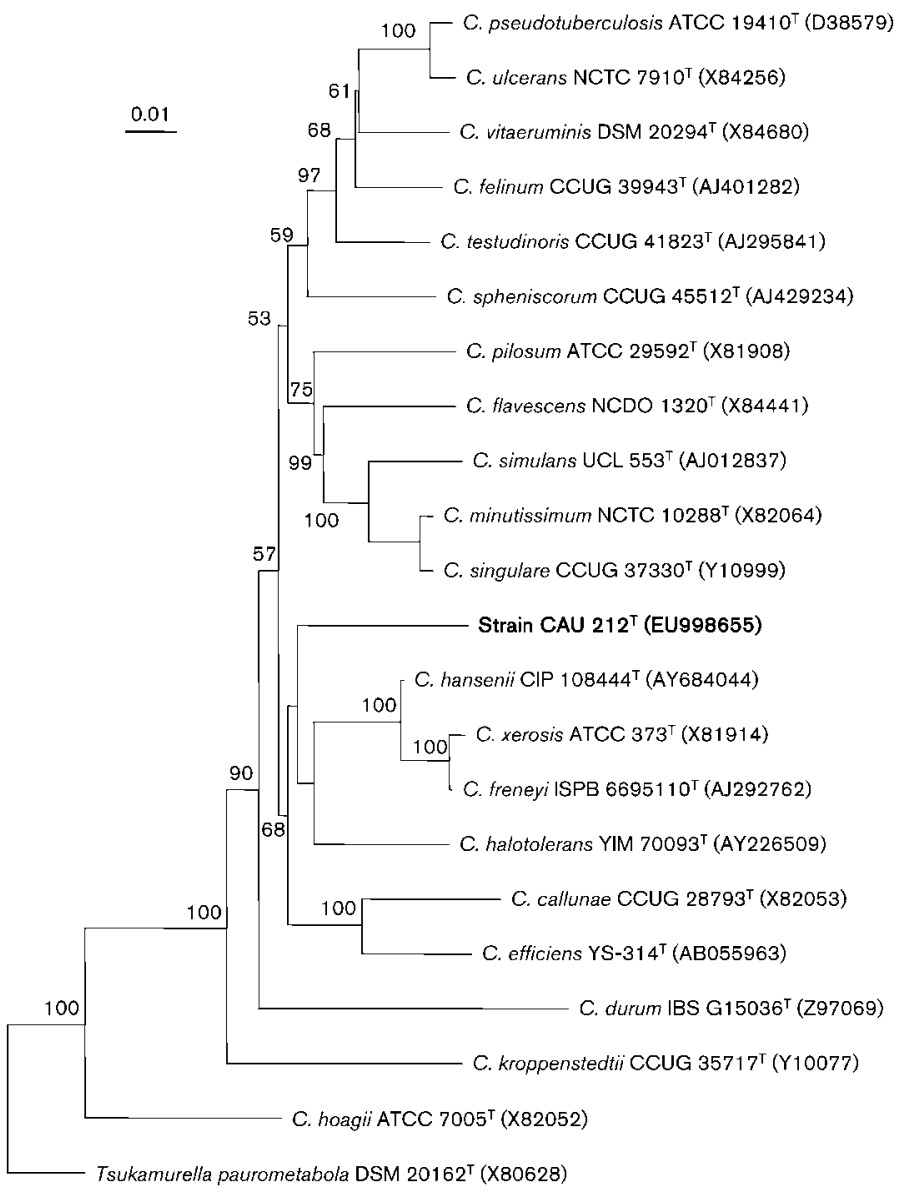

Fig. 1. Neighbour-joining phylogenetic tree based on nearly complete 16S rRNA gene sequences showing the relationships between strain CAU $212^{\top}$ and members of the genus Corynebacterium. Bootstrap values $(>50 \%)$ based on 1000 resamplings are shown at branch nodes. Tsukamurella paurometabola DSM $20162^{\top}$ was used as the outgroup. Bar, 0.01 substitutions per nucleotide position.

recognized members of this genus clearly indicate that strain CAU $212^{\mathrm{T}}$ represents a novel species of the genus Corynebacterium (Stackebrandt \& Goebel, 1994).

The phenotypic and chemotaxonomic data, together with the 16S rRNA gene sequence data, provide sufficient evidence to support the proposal that strain CAU $212^{\mathrm{T}}$ represents a novel species, Corynebacterium doosanense sp. nov.

\section{Description of Corynebacterium doosanense sp. nov.}

Corynebacterium doosanense (doo.san.en'se. N.L. neut. adj. doosanense belonging to Doosan, named after the Doosan group, the Foundation of Chung-Ang University where the taxonomic studies on this species were performed).

Cells are aerobic, Gram-positive, non-motile, non-sporeforming, irregular and club-shaped rods, $0.8-1.0 \times 1.0$ $1.2 \mu \mathrm{m}$ in size. Colonies (1-2 $\mathrm{mm}$ in diameter) are yellow and low-convex on GYEA media and yellow, opaque and low-convex on sheep blood agar after $48 \mathrm{~h}$ incubation at $30{ }^{\circ} \mathrm{C}$. Catalase, oxidase, reduction of nitrate and hydrolysis of hippuric acid are positive and activities are detected for sodium pyruvate, pyrazinamidase, esterase lipase (C8), leucine arylamidase and naphthol-AS-BI-phosphohydrolase. No activity is detected for pyrrolidonyl arylamidase, alkaline phosphatase, esterase (C4), lipase (C14), valine arylamidase, cystine arylamidase, trypsin, acid phosphatase, $\alpha$-chymotrypsin, $\beta$-glucuronidase, $\alpha$ - and $\beta$-galactosidase, $\alpha$ and $\beta$-glucosidase, $\alpha$-mannosidase, $\alpha$-fucosidase, $N$-acetyl$\beta$-glucosaminidase, leucine aminopeptidase, urease or hydrolysis of gelatin and aesculin. Acid production occurs only from glucose. Cell wall contains meso-diaminopimelic acid. Whole-cell hydrolysates contain mainly galactose and arabinose. Mycolic acids are detected. The DNA G $+\mathrm{C}$ content of the type strain is $53.5 \mathrm{~mol} \%$.

The type strain is CAU $212^{\mathrm{T}}\left(=\right.$ KCTC $19568^{\mathrm{T}}=$ CCUG $57284^{\mathrm{T}}$ ), isolated from activated sludge taken from a wastewater treatment plant in Yeongdeuk-gun, Republic of Korea.

\section{Acknowledgements}

This work was supported by the 21C Frontier Microbial Genomics and Application Center Program, Ministry of Education, Science and Technology (grant MG 08-0103-2-0), Republic of Korea. We are grateful to Dr Brian Hodgson (Prince of Songkla University) for providing editorial assistance with the English text.

\section{References}

Chen, H.-H., Li, W.-J., Tang, S.-K., Kroppenstedt, R. M., Stackebrandt, E., Xu, L.-H. \& Jiang, C.-L. (2004). Corynebacterium halotolerans sp. nov., 
isolated from saline soil in the west of China. Int J Syst Evol Microbiol 54, 779-782.

Chun, J., Lee, J.-H., Jung, Y., Kim, M., Kim, S., Kim, B. K. \& Lim, Y.-W. (2007). EzTaxon: a web-based tool for the identification of prokaryotes based on $16 \mathrm{~S}$ ribosomal RNA gene sequences. Int J Syst Evol Microbiol 57, 2259-2261.

Collins, M. D., Hoyles, L., Foster, G. \& Falsen, E. (2004). Corynebacterium caspium sp. nov., from a Caspian seal (Phoca caspica). Int J Syst Evol Microbiol 54, 925-928.

Felsenstein, J. (1985). Confidence limits on phylogenies: an approach using the bootstrap. Evolution 39, 783-791.

Felsenstein, J. (1989). PHYLIP - phylogeny inference package (version 3.2). Cladistics 5, 164-166.

Fernández-Garayzábal, J. F., Egido, R., Vela, A. I., Briones, V., Collins, M. D., Mateos, A., Hutson, R. A., Dominguez, L. \& Goyache, J. (2003). Isolation of Corynebacterium falsenii and description of Corynebacterium aquilae sp. nov., from eagles. Int J Syst Evol Microbiol 53, 1135-1138.

Fernández-Garayzábal, J. F., Vela, A. I., Egido, R., Hutson, R. A. Lanzarot, M. P., Fernández-García, M. \& Collins, M. D. (2004). Corynebacterium ciconiae sp. nov., isolated from the trachea of black storks (Ciconia nigra). Int J Syst Evol Microbiol 54, 2191-2195.

Feurer, C., Clermont, D., Bimet, F., Candréa, A., Jackson, M., Glaser, P., Bizet, C. \& Dauga, C. (2004). Taxonomic characterization of nine strains isolated from clinical and environmental specimens, and proposal of Corynebacterium tuberculostearicum sp. nov. Int J Syst Evol Microbiol 54, 1055-1061.

Gordon, R. E. \& Mihm, J. M. (1962). Identification of Nocardia caviae (Erikson) nov. comb. Ann N Y Acad Sci 98, 628-636.

Goyache, J., Ballesteros, C., Vela, A. I., Collins, M. D., Briones, V., Hutson, R. A., Potti, J., Garcia-Borboroglu, P., Domínguez, L. \& Fernández-Garayzábal, J. F. (2003a). Corynebacterium sphenisci sp. nov., isolated from wild penguins. Int J Syst Evol Microbiol 53, 10091012.

Goyache, J., Vela, A. I., Collins, M. D., Ballesteros, C., Briones, V., Moreno, J., Yorio, P., Dominguez, L., Hutson, R. \& FernándezGarayzábal, J. F. (2003b). Corynebacterium spheniscorum sp. nov., isolated from the cloacae of wild penguins. Int J Syst Evol Microbiol 53, 43-46.

Hall, V., Collins, M. D., Hutson, R. A., Lawson, P. A., Falsen, E. \& Duerden, B. I. (2003). Corynebacterium atypicum sp. nov., from a human clinical source, does not contain corynomycolic acids. Int $J$ Syst Evol Microbiol 53, 1065-1068.

Jukes, T. H. \& Cantor, C. R. (1969). Evolution of protein molecules. In Mammalian Protein Metabolism, vol. 3, pp. 21-132. edited by H. H. Munro. New York: Academic Press.
Klatte, S., Kroppenstedt, R. M. \& Rainey, F. A. (1994). Rhodococcus opacus sp. nov., an unusual nutritionally versatile Rhodococcusspecies. Syst Appl Microbiol 14, 355-360.

Lehmann, K. B. \& Neumann, R. (1896). Atlas und Grundriss der Bakteriologie und Lehrbuch der Speciellen Bakteriologischen Diagnostik. Munich: J. F. Lehmann (in German).

Marmur, J. (1961). A procedure for the isolation of deoxyribonucleic acid from microorganisms. J Mol Biol 3, 208-218.

Marmur, J. \& Doty, P. (1962). Determination of the base composition of deoxyribonucleic acid from its thermal denaturation temperature. J Mol Biol 5, 109-118.

Minnikin, D. E., Hutchinson, I. G., Caldicott, A. B. \& Goodfellow, M. (1980). Thin-layer chromatography of methanolysates of mycolic acid-containing bacteria. J Chromatogr A 188, 221-233.

Nam, S. W., Kim, W., Chun, J. \& Goodfellow, M. (2004). Tsukamurella pseudospumae sp. nov., a novel actinomycete isolated from activated sludge foam. Int J Syst Evol Microbiol 54, 1209-1212.

Renaud, F. N. R., Coustumier, A. L., Wilhem, N., Aubel, D., Riegel, P., Bollet, C. \& Freney, J. (2007). Corynebacterium hansenii sp. nov., an $\alpha$-glucosidase-negative bacterium related to Corynebacterium xerosis. Int J Syst Evol Microbiol 57, 1113-1116.

Saitou, N. \& Nei, M. (1987). The neighbor-joining method: a new method for reconstructing phylogenetic trees. Mol Biol Evol 4, 406-425.

Schleifer, K. H. \& Kandler, O. (1972). Peptidoglycan types of bacterial cell walls and their taxonomic implications. Bacteriol Rev 36, 407-477.

Stackebrandt, E. \& Goebel, B. M. (1994). Taxonomic note: a place for DNA-DNA reassociation and $16 \mathrm{~S}$ rRNA sequence analysis in the present species definition in bacteriology. Int J Syst Bacteriol 44, 846-849.

Thompson, J. D., Gibson, T. J., Plewniak, F., Jeanmougin, F. \& Higgins, D. G. (1997). The CLUSTAL_X windows interface: flexible strategies for multiple sequence alignment aided by quality analysis tools. Nucleic Acids Res 25, 4876-4882.

Vela, A. I., Gracia, E., Fernández, A., Domínguez, L. \& FernándezGarayzábal, J. F. (2006). Isolation of Corynebacterium xerosis from animal clinical specimens. J Clin Microbiol 44, 2242-2243.

von Graevenitz, A. \& Funke, G. (1996). An identification scheme for rapidly and aerobically growing gram-positive rods. Zentralbl Bakteriol 284, 246-254.

Yassin, A. F. (2007). Corynebacterium ureicelerivorans sp. nov., a lipophilic bacterium isolated from blood culture. Int J Syst Evol Microbiol 57, 1200-1203.

Yassin, A. F. \& Siering, C. (2008). Corynebacterium sputi sp. nov., isolated from the sputum of a patient with pneumonia. Int J Syst Evol Microbiol 58, 2876-2879.

Yassin, A. F., Kroppenstedt, R. M. \& Ludwig, W. (2003). Corynebacterium glaucum sp. nov. Int J Syst Evol Microbiol 53, 705-709. 